\title{
A Career Perspective on Citrus Rootstocks, Their Development, and Commercialization
}

\author{
William S. Castle ${ }^{1}$ \\ University of Florida, IFAS, Citrus Research and Education Center, 700 \\ Experiment Station Road, Lake Alfred, FL 33850
}

\begin{abstract}
"No problem in citrus culture is worthier of painstaking research than the one having to do with rootstocks. The whole gamut of citrus fruit production is affected by the relation of rootstock to scion and the adaptability of different combinations to the environment. Something is known but much remains to be found out."

-H.H. Hume (1957)
\end{abstract}

Professor Hume was right: rootstocks are critical and much is still to be learned. Rootstocks and scions are the foundation of many tree fruit industries of the world. Together, those components establish profitability, but it can be argued that the rootstock is the critical component; otherwise, scions would be grown on their own roots everywhere. There is no precedent for the failure of a citrus industry because of an inadequate scion variety, but serious problems have occurred because of a less than satisfactory rootstock. Therefore, after 35 years in the field conducting rootstock and scion evaluation research and working with our University of Florida citrus plant improvement team, here is an historical perspective on citrus rootstocks along with some observations and reflections on the human or social side of research and grower cooperation.

It is well established from decades of experience that citrus rootstocks bring many advantages and profitability to commercial enterprise. In some instances, citrus rootstocks are the sole determining element that allows citrus to be grown in particular circumstances. Yet, despite their popularity and necessity, every rootstock has one or more undesirable traits that preclude its universal use. Those limitations have sometimes been discovered during research and development; at other times, they have not been revealed until after significant commercial use.

Until the mid-1800s, citrus was grown primarily as seedlings. Commercial operations were limited in scope and size as compared with today and certainly were not operated with the same level of technical knowledge or experience. It is generally known that two grand disease events were apparently responsible for creating the initial

Received for publication 11 Sept. 2009. Accepted for publication 18 Oct. 2009.

${ }^{1}$ To whom reprint requests should be addressed; e-mail bcastle@ufl.edu. interest in citrus rootstocks and changing the direction of citriculture; first, the damaging effects of Phytophthora foot rot when ownrooted sweet orange trees were common. Many of those trees were actually seedlings with their own inherent disadvantages. The second disease problem was citrus tristeza virus, which devastated trees of sweet orange and other varieties on the highly susceptible sour orange, the most popular rootstock in many parts of the world before the spread of the virus. As these problems spread and were encountered by citrus growers worldwide, budding, i.e., using a rootstock, became the accepted practice. Grafting or budding is actually a centuries old horticultural technique but one not widely practiced in citriculture until the late 1800 s or the early 1900 s. It was not until the $1940 \mathrm{~s}$, however, that the cause of tree decline on sour orange came to be associated with a graft-transmissible entity later shown to be a virus.

The "modern" era of citrus rootstock use and subsequent history could be described as beginning in the early part of the 20th century in response to the diseases mentioned (Webber, 1967). Field trials with usually a small number of rootstocks were initiated and eventually followed with ones of larger scale (Batchelor and Rounds, 1948; Gardner et al., 1967; Moreira and Salibe, 1969). Those early trials also revealed the importance of other unknown virus and viroid diseases that affected the rootstocks being evaluated. However, they were conducted under considerable constraints, in retrospect, given the genetic and breeding tools available in 2009.

Formal breeding programs have emerged and use new technologies such as somatic hybridization and molecular markers that are altering and expanding the range of possibilities for genetic manipulation leading to improved rootstocks (Kahn, 2007). As a result, there is a new era of citrus rootstock research and development underway that is linked to different ways of thinking about rootstocks and their role in future citrus orchards. It is conceivable that genetic advances might eventually eliminate the need for rootstocks as rootstock traits are incorporated into the scion variety.

\section{Importance of Citrus Rootstocks}

The importance of a citrus rootstock rests on the subtle distinction between the general reasons why rootstocks are used and individ- ual rootstock characteristics. A rootstock primarily provides a reduction in juvenility (time to bearing) and tree vigor when compared with seedling trees; thus, citrus trees propagated with a rootstock combined with a pathogen-free scion bring a much improved degree of uniformity and consistency to an orchard. Secondarily, rootstocks have many individual characteristics that contribute in positive ways to the performance of a citrus tree (Table 1). They influence various horticultural traits and provide tolerance to pests and diseases and certain soil and site conditions that contribute significantly to orchard profitability. Also important are rootstock nursery traits such as the degree of nucellar embryony that is related to the ease, expense, and consistency of propagation. These reasons combined explain why propagation of citrus trees with rootstocks has long been preferred over the use of scion cuttings taken from mature trees.

The existence of citrus rootstock choices has historically meant that: 1) sour orange could be replaced, thus averting future disasters from large-scale tree loss resulting from citrus tristeza virus infection; 2) citrus orchards could be grown on marginal soils and locations because rootstocks suitable for high $\mathrm{pH}$ soils, salinity problems, or colder areas were available; 3 ) particular objectives could be met by selecting not the best overall choice, but by selecting a rootstock for one specific purpose like large fruit size, for example, the use of rough lemon rootstock for navel oranges or Volkamer lemon for 'Murcott'; 4) rootstocks with complementary tolerances to pests and diseases could be selected to reduce the risk of tree loss; and 5) the harvest season could be extended because of the effect of rootstock on juice Brix/acid ratio.

Today, breeding citrus rootstocks continues with emphasis on many characteristics, but especially on creating rootstocks that reduce tree size beyond what is currently possible among commercial rootstocks. Sizecontrolling rootstocks are important for higher density orchards, and rootstocks that induce scion precocity are needed for significant cropping to begin early. Of course, new rootstocks must also lead to excellent yields of high-quality fruit and possess other key tolerances.

Distinctiveness of citrus rootstocks versus other tree fruit rootstocks. The long list of citrus tree performance factors attributable to the rootstock (Table 1) is difficult to match by any other tree fruit. Yield, for example, can be affected by the choice of rootstock in apple, pear, or peach, but in those instances, fruit quality and yield efficiency are usually maintained by canopy management rather than rootstock choice (Castle, 1995). Rootstocks for deciduous tree fruit crops are usually selected for tree size control and their tolerance to various pests or diseases. Another distinction is the nature of the citrus fruit itself and its morphology and physiology. The citrus fruit consists of small sacs filled with juice. The composition of the juice 


\begin{tabular}{|c|c|c|}
\hline & Attribute & Remarks on attributes as a rootstock selection criterion \\
\hline 1 & Yield & A major consideration \\
\hline 2 & Precocity & A special factor as interest in higher-density plantings increases \\
\hline 3 & Yield efficiency & Can be important, but not usually a selection criterion \\
\hline 4 & Fruit quality & A major factor for fresh fruit growers \\
\hline 5 & Fruit size & Important enough to be considered separately from quality \\
\hline 6 & Juice quality & Brix and acid are affected; a major factor for growers of both fresh and processing fruit \\
\hline 7 & Tree growth & Usually considered in terms of vigor and eventual tree size, a criterion that is increasing in importance \\
\hline 8 & Compatibility & Scion-rootstock vegetative compatibility is often important \\
\hline 9 & Ease of propagation & Largely a matter of seed production and degree of nucellar embryony \\
\hline 10 & Shoot flushing & A new criterion related to Huanglongbing and spread by psyllids \\
\hline 11 & Mineral nutrition & Not usually a selection criterion, but there are rootstock effects \\
\hline 12 & Salinity & In some instances, an important selection criterion \\
\hline 13 & Clay soil & High content or sol horizons can affect a rootstock decision \\
\hline 14 & High soil $\mathrm{pH}$ & A very important factor with trifoliate orange-based rootstocks \\
\hline 15 & Wet soil (flooding) & Not usually a selection factor but can be important \\
\hline 16 & Drought & Modern irrigation methods usually preclude this as a selection factor \\
\hline 17 & Cold (freezes) & Often considered in regions threatened by chronic cold \\
\hline 18 & Citrus blight & At one time, a major consideration, but less so now in Florida \\
\hline 19 & Phytophthora rots & Still an important factor in rootstock decisions \\
\hline 20 & P. palmivora/root weevil complex & A problem specific to Florida involving a particular species of Phytophthora fungus and Diaprepes root weevil \\
\hline 21 & Root weevils & A troublesome problem at times in some areas \\
\hline 22 & Burrowing nematode & A problem in Florida for which specific rootstocks are used \\
\hline 23 & Citrus nematode & A more universal problem with specific rootstock options \\
\hline 24 & Tristeza virus & A serious threat with some rootstock options \\
\hline 25 & Exocortis and xyloporosis viroids & Not generally a threat today with clean budwood \\
\hline
\end{tabular}

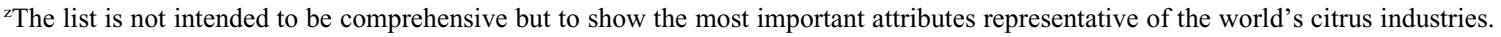

determines flavor and is affected by plant water relations. Rootstocks are linked to plant water relations and consequently have a role in the taste of the fruit (Albrigo, 1977). The apple fruit has a different morphology and its flavor and texture are not so directly affected by the rootstock. Furthermore, apples are a climacteric fruit; citrus is nonclimacteric. That difference is related to the virtual absence of a rootstock effect on quality in fruits such as apple and emphasizes the importance of citrus rootstocks.

\section{History of Citrus Rootstocks}

There are at least three reasons for defining an early era ( $\approx 1900$ to 1970$)$ and modern era (1970 forward) of citrus rootstocks: 1) commercial enterprises of today's scale did not emerge until toward the end of the early era. As a result, the value of a rootstock, even the critical need for the right rootstock, was known but was not fully exploited because rootstock science and commercial experience were relatively undeveloped; 2) international trade in citrus fruit and products was established on a larger scale than during previous decades partly because new rootstocks allowed citrus to be grown in large plantations with fewer risks than before; and 3) budwood protection programs were established toward the end of the early era and advanced in the modern era. Those programs offered new choices because rootstocks with virus and viroid susceptibilities could then be used with clean budwood.

There are essentially 11 rootstocks (see following numbered rootstocks) that formed the world's portfolio during three historical phases. Most of those rootstocks have been known for decades and are the mainstay of the global citrus industry today. Few additions have been made since then, but new hybrids are being produced that may change the situation in the new era.

Phases I and II occurred in the early era and Phase III in the modern era. In the history of rootstocks, Phase I is the world story of sour orange (1) rootstock, the only rootstock that might be considered as universal because of its widespread use. That phase was followed by two others, the first one involving rootstocks like Cleopatra mandarin (2), rough lemon (3), Volkamer lemon (4), and sweet orange (5) as choices of interest until replacements were found for sour orange. The third phase began when the citrange and citrumelo rootstocks were discovered. They were shown initially to have enough similarities to sour orange to be quickly accepted commercially in Florida and California and of sufficient promise to be included in rootstock evaluation trials elsewhere.

All of sour orange's excellent attributes are well known along with its major limiting factor, susceptibility to citrus tristeza virus. That virus was responsible for virtually eliminating or forcing drastic changes to the citrus industries in places like Australia, Argentina, Brazil, the United States, the Mediterranean region, and South Africa. In other parts of the world, like Mexico where the virus or vectors are not present at a damaging level, sour orange remains a part of the rootstock portfolio, but its future is threatened. The spread of the efficient vector, the brown citrus aphid, is a major factor in that threat. There are a few areas remaining where sour orange continues as the rootstock for lemons, the only common commercial scion that can survive tristeza when grown on sour orange rootstock. Sour orange remains the major rootstock in Italy.

Phase II rootstocks achieved different levels of commercial importance. Rough lemon was at one time the major rootstock in Florida for processed oranges. Rough lemon also has a history as a rootstock for fresh fruit in South Africa where it produced good-sized navel oranges and California where it had some use as a rootstock for lemons; likewise, Volkamer lemon attracted similar interest, but not usually on the scale of rough lemon. Cleopatra and other mandarins have often been chosen as the rootstock for mandarin and mandarin-hybrid scion varieties. Their use with those scions has remained essentially constant; however, commercial experience consistently revealed their slowness to bear and small fruit size limitations that preclude their use with other scions.

Phase III begins with trifoliate orange (6), a rootstock with a long, successful, and traditional history as the major rootstock in Japan and China. Trifoliate orange also has a significant place in northeast Argentina and Uruguay for fresh fruit and to a limited extent in Australia and California for the same purpose. In some parts of the world, trifoliate orange did not become an important rootstock until sometime in the modern era. It had a reputation in its early history of being erratic. It was subsequently learned that exocortis viroid was the reason for that reputation. The commercial prospects for trifoliate orange were also improved when it became apparent that there were selections categorized primarily by flower size that affected budded tree size. Among those is the selection Flying Dragon that produces the most size-controlled trees of any rootstock. For that reason, it has attracted interest among rootstock breeders and for commercial use, largely in Argentina and in Costa Rica where substantial numbers of lemons and sweet orange trees, respectively, are being planted on this rootstock.

Citranges and citrumelos, hybrids of trifoliate orange with sweet orange and 
grapefruit, respectively, represent the next generation of rootstocks and they changed the world by becoming the dominant rootstock types in many of the world's largest citrus industries. It is astounding that in the 1904 USDA Yearbook of Agriculture, Willits citrange was described as one of 40 citranges that all came as seed from a single fruit. Willits was described as the second citrange showing potential value, but it was Morton citrange that was initially thought to be the most promising based on research in California. Eventually, Carrizo (7) and Troyer (8) emerged as the top commercial rootstocks. Their history shows, however, that they originated in 1909 in California from the same hybrid seedling (Savage and Gardner, 1965). It was their subsequent distribution to Florida, Alabama, and Texas plus a little intrigue involving fire and a Russian delegation that resulted in the plants being separately named in the 1930s. The question persists as to whether they are the same plant. Modern molecular tools indicate that they have the same genotype and field comparisons support that contention (McCarty et al., 1974).

Carrizo citrange first became a commercial rootstock in Florida in the 1970s where it essentially replaced rough lemon and eventually was the rootstock for more than $40 \%$ to $50 \%$ of annual nursery propagations (Castle, 1987; Wutscher, 1979). It remains popular, especially for Valencia sweet orange, but is no longer the number one choice because of problems with citrus blight. Carrizo citrange gained dominance in Spain as well, but its sensitivity to calcareous soils has limited it potential use. Carrizo and Troyer citranges have been widely evaluated in places other than in Florida and California and have slowly been adopted in some countries as a replacement for sour orange.

Troyer citrange became popular in California as early as the 1950s and was dominant for 20 years thereafter (Ferguson et al., 1990). Before its use, sweet orange and sour orange were the common rootstocks along with more limited use of rough lemon and Cleopatra mandarin. However, in the 1940s, citrus tristeza virus was ravaging California citrus trees on sour orange; thus, Troyer became the leading rootstock. Troyer also proved satisfactory for Lisbon-type lemons, but not Eureka types because of compatibility issues with trifoliate orange and its hybrids. Troyer citrange is a common rootstock for the popular Limoneira 8A lemon scion in Argentina, the world leader in lemon production. In California and other industries, Citrus macrophylla (9) was discovered as a suitable rootstock for lemon.

Phase III included Swingle citrumelo (10), an important rootstock that basically followed the citranges and is still being evaluated and adopted. It has an interesting history that is often invoked as the main evidence of the time, commitment, and serendipitous nature of the life of a rootstock from the point of creation to commercial acceptance. Dr. Walter Swingle, USDA, made the hybrid in Florida in 1907 to transmit the cold hardiness attributes of trifoliate orange to scion cultivars, not to develop a new rootstock. It was tested as accession CPB 4475. The rootstock was widely studied in Florida, but it was the research of another USDA scientist in Texas, Dr. Heinz Wutscher, that attracted the most attention to Swingle citrumelo (Wutscher, 1979). The official release of Swingle citrumelo in 1974 was followed by a largely unprecedented rootstock shift to this rootstock in Florida as a replacement for Carrizo citrange. Swingle citrumelo is still the most popular general-use rootstock in Florida; however, in addition to the well-known intolerance of trifoliate orange and its hybrids to calcareous soil, other exceptions have been noted. It is not suitable for use in certain soil situations related to soil horizons high in clay or low in organic matter content (Bauer et al., 2005). Its poor performance in such soils was also reported in Texas, but not fully recognized until the experiences in Florida.

The historical shift away from sour orange in Brazil was different. Rangpur lime (11) was the preferred choice when sour orange was no longer a viable option. However, tree decline became a serious matter until it was learned that exocortis viroid was the cause. The problem was eliminated with the advent of clean budwood sources. Rangpur lime continues as the main rootstock in Brazil because trees are productive and drought-tolerant.

During the course of Phases I to III, a number of rootstocks had a minor commercial history. More recently, other promising citranges like C-35 have been evaluated. C35 was first used on a commercial scale in the Dominican Republic and proved to be very satisfactory on their volcanic soils and in the presence of Diaprepes weevils. A Cleopatra mandarin $\times$ trifoliate orange hybrid (x639) was produced in South Africa. Other mandarintrifoliate hybrids such as US 897 and US 812 and have been produced and appear to be very promising along with those of the breeding programs in the United States, Argentina, Brazil, and Spain.

\section{Social Aspects of Citrus Rootstocks}

Breeding citrus rootstocks, conducting their evaluation followed by some form of release, and then their adoption by growers are all human endeavors, which mean that the outcomes are subject to the personalities of people and their reactions to circumstances. Therefore, there can be little doubt that the history of citrus rootstocks has a human or social component. That component has affected or perhaps even determined the course of citrus history and so should be considered important in any discussion of citrus rootstocks. Here are a few examples of the alignment of rootstock history, people, and events:

Why did it take 67 years from hybridization to the release of Swingle citrumelo, and why did extensive field trials not begin until the mid-1940s? The answer to that question does not involve any deliberate social interference.
However, between 1907 and the 1940s, many citrus operations had not matured beyond a localized fresh fruit business; two world wars had occurred and the means and market for large-scale fresh and juice fruit operations were yet to arrive. The world was reasonably content with the available rootstocks except for the need for ones with tristeza and Phytophthora tolerance. The imperatives and opportunities that are in place today are much more demanding on citrus businesses than those of 1940s. Also, citrumelos were a new and relatively underevaluated class of rootstocks. In the $1940 \mathrm{~s}$, there was considerable interest in tristeza-tolerant rootstocks and Swingle citrumelo was tested in the United States, Brazil, and Argentina where it was shown to be tolerant. The human and social elements in this story are mostly ones of timing, circumstances, and interest.

Recent rootstock research in Florida. The arrival of canker followed by Huanglongbing (HLB) has almost eliminated rootstocks as a common topic of discussion or concern. Why? Because some growers feel that unless control is gained over HLB, the Florida citrus industry may not survive, and they are satisfied with the currently available rootstocks. Thus, financial resources have been directed to the HLB problem and the creation of tolerant plants that may or may not be rootstock-related. Citrus diseases can have a stimulating or depressing effect on rootstock research.

Rootstock research in South Africa. Although not a large industry by international standards (less than $2 \%$ of world production), South Africa has one of the most significant fresh fruit export businesses with exacting standards that can be traced back to the rootstocks used. Also, as one of the citrus industries badly affected by tristeza, a rootstock improvement program has been underway for many years. That program languished for awhile and was not rejuvenated until the 1980s. Why? Perhaps, again, because of personal, institutional, and industry priorities that, although realistic, may have gone unchallenged given the longterm commitment needed to develop new rootstocks.

Tradition and circumstances. The introduction of new rootstocks can face a number of powerful obstacles such as tradition and the normal industry condition. "Tradition" can exert a strong influence. Oftentimes, the balance of good versus negative rootstock attributes is positive and the rootstock continues to have commercial acceptance. Until that balance changes in some negative way as perceived by growers, introducing a replacement rootstock has not been easy. Carrizo citrange is a good example. Florida growers have had some problems with Carrizo citrange, but those problems have only reduced interest in the rootstock, not replaced it. In California currently, Carrizo citrange is increasing in popularity and replacing Troyer. That changeover is difficult to understand given the very similar performance usually experienced among trees on either rootstock. In other circumstances, one rootstock trait 
can be identified and eliminate a rootstock, e.g., sour orange and tristeza; however, the sour orange story does not end there. Sour orange was the traditional rootstock in Florida partly because it grows well in a broad range of soil types. That particular tradition (grower experience) is a powerful factor because it explains why some growers dissatisfied with other choices are returning to sour orange.

Sometimes there simply is not a place in a citrus industry for a new rootstock or technology. In Australia, the use of viroids to control tree size was a well-researched and developed technology, but it was never used. The long-term integrity of Australian citrus orchards is such that there are few opportunities resulting from tree losses, and so on, to replace orchards and introduce new rootstocks or technologies.

\section{Commercial Rootstock Selection}

The selection process is the ultimate human experience in the realm of rootstocks. It is when good science plus tradition, experience, and circumstances come together as the most meaningful forces determining the choices. It is a time when a new rootstock may begin its commercial history. It is a time for the associated researchers to enjoy a moment of pride and satisfaction, and it should be a time when researchers and growers reflect on their long-standing joint efforts to define rootstock needs and make commercial rootstock decisions. Nevertheless, I can attest to the fact that the process remains largely a mystery. From my perspective, a rootstock never seems to be selected strictly on its merits as revealed from research and some commercial experience.

I can also attest to the fact that viewpoints on rootstock decisions can be quite different and founded on different motivations. At times, rootstock choice is certainly as much a philosophical decision as a technical decision. Researchers want to create and develop better rootstocks. Growers want to make money. I attempted to bridge that potential gap by conducting a long-term field trial with 'Valencia' orange on 12 rootstocks at two locations in Florida (Castle et al., 2010). Yield and juice quality data were collected for 14 years along with tree loss to blight. Blighted trees were removed and replaced annually with another tree on the original rootstock. All the data were used for a cash flow analysis. We learned that despite individual rootstock characteristics, yield and planting density had the greatest effect on the financial results. In fact, the yield of the trees on Volkamer lemon was so large that although $50 \%$ of the trees were lost to citrus blight, those trees had the highest income. We also made adjustments to tree spacing and recalculated cash flow to accommodate, e.g., the smaller size of trees on Swingle citrumelo. Those trees had improved financial performance but still did not exceed Volkamer lemon or Carrizo citrange. Why then is Swingle citrumelo the most popular rootstock in Florida? The answer is because of risk and its perception. "Risk" is the single factor that integrates all human components in the citrus rootstock business from research to commercialization. Swingle citrumelo may not produce the most income, but it has fewer perceived risks than other rootstocks and possesses certain attributes that are viewed as relatively high value like tolerance to many pest and disease problems leading to long-term survivability, acceptable yield, and good juice quality.

\section{Citrus Rootstock Category as a Selection Criterion}

Long-term observation suggests that citrus rootstocks can be placed into three categories: 1) replacement rootstocks, ones that provide a large improvement or order of magnitude leap in attributes, e.g., a tristezatolerant sour orange. The improvement would result in the new rootstock being accepted most quickly for commercial use; 2) alternative rootstocks, ones that are somewhat better than existing rootstocks, but their improvements are primarily incremental or in a particular trait. An example is C-35 citrange, which has many of the same traits as any citrange, but it also has others, including some control of tree size that has resulted in increasing interest in it as a commercial rootstock; and 3) special purpose rootstocks. Kuharske citrange is an example. It is being used in Florida because it is a citrange and has exceptionally good tolerance to burrowing nematodes, a problem in some areas of the citrus industry. These categories are important because placement in a particular category as a result of grower perception and experience may determine the subsequent history of a rootstock.

\section{Cooperative Research}

In Florida, we do not have the field resources for an aggressive field research program. However, my colleagues and I are fortunate to have a substantial history of cooperative field study with growers. What I have never understood is why every grower is not a participant. We depend on grower cooperation to conduct field trials. Each partner benefits from the relationship at little to no cost to the grower. It is a classic winwin situation.

The cooperative projects are highly variable in scope and intent, so it is very easy to arrange something for any grower. Cooperator trials usually involve a commercial scion variety so there is an income; no special cultural or management issues are introduced, harvesting is by a commercial crew, and data collection is mostly by the researchers with no impact on the grove operation. For the small farmer, a project can be as simple as a few trees on a few rootstocks placed almost anywhere for observation. The learning potential is considerable, but the main advantage to the grower is to learn at minimal expense what new rootstocks will do with his or her management and conditions.

\section{The Future}

Although citrus has been cultivated in some form for centuries, most the world's citrus industries as we know them today are $\approx 100$ years old or less. Yet history shows that during that period, new commercial rootstocks resulted from only two mechanisms: 1) searching and selecting among existing plants; or 2) breeding new hybrids and selecting among them. Of the 11 rootstocks identified here, most were existing species or selections and citrus rootstock breeding has relied heavily on one parent, trifoliate orange. Today, trifoliate orange remains a singularly important source of genetic traits to be captured in hybrids with new parental combinations, especially with various mandarins.

Very little has been or is simple and easy in the field of citrus rootstocks. Rather than try to predict the near or far future, perhaps some of the following will be factors of some consequence:

- The potential to produce new citrus rootstocks by either conventional means or in combination with modern technologies is substantial and demonstrated. Therefore, it is interesting to consider whether those approaches will be the only means of creating new rootstocks in the future or if searching and selection will compete with modern breeding and then, what role social aspects will play. The social component, in this instance, is sustained human interest in developing new rootstocks.

- There may be shifts in priorities. Yield and fruit and juice quality are likely to remain key rootstocks attributes, but in the words of Dr. Bill Bitters, the dean of rootstock research, "Rootstocks once established are not very susceptible to change; however, occasionally something happens which requires a change." Modern tools to identify genetic elements related to specific traits and to transfer them from one source to another, and quickly confirm that the desired event has occurred, allow creative concepts for rootstock improvement. As the knowledge base increases, perhaps new rootstocks designed in response to particular concerns could more readily be produced. "New" rootstocks could also include well-established rootstocks that only need to have certain aspects modified or simply be rediscovered. Willits citrange did not fulfill its initial expectation, but today, it may have serious merit as a size-controlling rootstock.

- Modern molecular tools have provided insights into the genetic background of citrus species and selections. As a result, geneticists are now attempting to recreate and maybe improve on rootstocks essentially lost to the world portfolio. Sour orange is the best example. Its progenitors appear to be mandarin and pummelo and 
there are several researchers today making hybrids with those parents.

- Rootstock evaluation will be based on economic interpretation and require no more than 10 years.

To close, here is a quote from the recently published book, "Dangerous Games, The Uses and Abuses of History," written by a historian on the subject of history:

"If the study of history does nothing more than teach us humility, skepticism and awareness of ourselves, then it has done something useful"

- Margaret MacMillan (2009)

\section{Literature Cited}

Albrigo, L.G. 1977. Rootstocks affect 'Valencia' orange fruit quality and water balance. Proc. Intern. Soc. Citriculture 1:62-65.
Batchelor, L.D. and M.B. Rounds. 1948. Choice of rootstocks, p. 169-222. In: Batchelor, L.D. and H.J. Webber (eds.). The citrus industry. 1st Ed., Vol. II. Univ. Calif. Press, Berkeley, CA.

Bauer, M., W.S. Castle, B.J. Boman, and T.A. Obreza. 2005. Economic longevity of citrus trees on Swingle citrumelo rootstock and their suitability for soils of the Indian River region. Proc. Fla. State Hort. Soc. 118:24-27.

Castle, W.S. 1987. Citrus rootstocks, p. 361-399. In: Rom, R.C. and R.F. Carlson (eds.). Rootstocks for fruit crops. Wiley, Hoboken, NJ.

Castle, W.S. 1995. Rootstocks as a fruit quality factor in citrus and deciduous tree crops. N. Z. J. Crop Hort. Sci. 23:383-394.

Castle, W.S., J.C. Baldwin, R.P. Muraro, and R. Littell. 2010. Performance of 'Valencia' sweet orange trees on 12 rootstocks at two locations and an economic interpretation as a basis for rootstock selection. HortScience 45: (accepted)

Ferguson, L., N. Sakovich, and M. Roose. 1990. California citrus rootstocks. Univ. Calif. Ext. Publ. 21477.
Gardner, F.E., D.J. Hutchison, G.E. Horanic, and P.C. Hutchins. 1967. Growth and productivity of virus-infected Valencia orange trees on twenty-five rootstocks. Proc. Fla. State Hort. Soc. 80:89-92.

Kahn, I. (ed.). 2007. Citrus genetic, breeding and biotechnology. CAB International, Cambridge, MA.

McCarty, C.D., W.P. Bitters, and D.A. Cole. 1974. Comparisons between Troyer and Carrizo citrange. Citrograph 59:294-310.

Moreira, S. and A.A. Salibe. 1969. The contribution of research for the progressive changes in citrus rootstocks for South America. Proc. First Intern. Citrus Symposium. 1:351-357.

Savage, E.M. and F.E. Gardner. 1965. The origin and history of Troyer and Carrizo citranges. California Citrograph 40:255, 276-278.

Webber, H.J. 1967. History and development of the citrus industry, p. 1-39. In: Reuther, W., H.J. Webber, and L.D. Batchelor (eds.). The citrus industry. Vol.1. Univ. Calif., Oakland, CA.

Wutscher, H.K. 1979. Citrus rootstocks. Hort. Rev. (Amer. Soc. Hort. Sci.) 1:237-269. 